Тамара Вученовић

УДК 026/027:316.776

Радио Београд

доИ https://doi.org/10.18485/

melissa.2016.15.2.ch20

\title{
НОВА ПАРАДИГМА КУЛТУРЕ: ПАРТИЦИПАТИВНЕ ПРАКСЕ У САВРЕМЕНИМ ИНСТИТУЦИЈАМА КУЛТУРЕ
}

\section{Сажетак}

У раду Нова парадигма културе: партиципативне праксе у савременим институцијама културе указано је на веб и интернет технологије као темељ партиципативности, на појам партиципативних пракси у култури, као и на тврдње Нине Симон да институције културе могу да се поново повежу са јавношћу и покажу релевантност у савременом животу тако што ће позвати људе да се активно укључе као културни учесници, а не као пасивни конзументи. Такође, у раду је указано и на истраживања која показују да се сарадња са публиком уз примену ИКТ-а још увек посматра као релативно нова и недовољно искоришћена могућност, те на чињеницу да је неопходно посветити довољно пажње балансирању између потреба институције и потреба појединца, поштовању ауторских права и бројним изазовима који прате реализацију партиципативних пројеката у савременим институцијама културе.

Кључне речи: култура, ИКТ, веб, партиципативне праксе, институције културе, нова парадигма.

„Веб 1.0 водио је људе ка информацији, Веб 2.0 води информацију ка људима. Тачно тако." ${ }^{1}$

Анализирајући интернет технологије из угла знања - стварања, неговања и изградње знања уз помоћ дигиталних алатки, налазима истраживања спроведеног у Великој Британији 2011. године, ${ }^{2}$ показа-

1 Paul Miller, „Web 2.0: Building the New Library”, Web Magazine for information professionals, (2005), http://www.ariadne.ac.uk/issue45/miller (preuzeto 08. 01. 2013).

2 Marie Joubert i Joceylin Wishart, „Participatory practices: Lessons learnt from two initiatives using online digital technologies to build knowledge", Computers and education 59 (2012), 111., prema: Adamic, L. A., Wei, X., Yang, J., Gerrish, S., Nam, K. K., \& Clarkson, 
но је да интернет омогућава без преседана великом броју различитих појединаца да дају свој допринос стварању знања. Дакле, корисници партиципирају у развоју веб технологија и у стварању глобалног корпуса знања и информација заснованог на партиципативном вебу. Важно је нагласити да се интернет и веб у свакодневној комуникацији често употребљавају као синоними, иако веб представља заправо само једну од интернет технологија. Веб 2.0 је термин који је скован да би се означила разлика у односу на Веб 1.0 и, према Џеку Манесу (Jack Mannes), који ове промене сматра изузетно великим, први су га употребили и дефинисали Тим О’Рајли и Дејл Дохерти (Tim O’Reilly, Dale Dougherty) 2004. године, да би њиме описали трендове и бизнис моделе који су опстали након пропасти тржишта технологија 1990. године ${ }^{3}$. Ови аутори увиђају да технологије имају бројне заједничке одлике: интерактивност, динамичност, колаборативне су по својој природи и линија између креирања и потрошње садржаја више није тако јасна. „Веб 2.0 је мрежа као платформа, која обухвата све конектоване уређаје. Веб 2.0 апликације су оне које у највећој мери чине суштину предности ове платформе: испорука софтвера као сервиса који се континуирано апдејтују и што их више људи користи - они постају бољи, конзумирање и ремиксовање података из различитих извора (укључујући и индивидуалне кориснике који обезбеђују своје сопствене податке и сервисе) у форми која дозвољава њихово ремиксовање од стране других корисника, стварање мрежних ефеката кроз тзв. архитектуру партиципације, испоруку богатог корисничког искуства итд." ${ }^{4}$ Дакле, основна карактеристика овог концепта је учествовање корисника у далеко већем обиму, са новим могућностима и карактеристикама.

Концепт Веб 2.0 је, дакле, присутан дуже од десет година и данас већ можемо да констатујемо да постоји обимна литература о овој теми. Од бројних карактеристика Веб 2.0, поред учешћа корисника, поменућемо најважније: повећан обим учествовања корисника у креирању различитих садржаја и њихово умрежавање и

G. S. (2010). Individual focus and knowledge contribution. First Monday, 15(3).

3 Jack M. Mannes, "Library 2.0 Theory: Web 2.0 and Its implications for Libraries”, Webology, Volume 3 (2006), http://www.webology.org/2006/v3n2/a25.html (preuzeto 04. 05. 2011).

4 Tim O’Reilly, „Web 2.0: Compact Definition?”, http://radar.oreilly.com/2005/10/web-20compact-definition.html (pristupljeno 14. 06. 2012). 
повезивање на глобалној рачунарској мрежи (најпознатији сервиси и технологије: блог, RSS, форуми, подкаст, вики, софтвери за дељење садржаја на интернету, онлајн платформе за друштвено умрежавање итд.), потенцијално велики обим интерактивности као кључна одлика ове комуникације која може да се одвија у реалном времену, „дугачак реп" (long teil), 5 односно ефекат који омогућава да се посебно креираним услугама које су намењене специфичној групи корисника задовоље потребе великог броја мањих корисничких група, развој база података које садрже тзв. колективно знање, односно знање генерисано од стране чланова онлајн заједнице итд.

Дакле, генерисање садржаја од стране корисника и њихово учешће у мултимедијалном технолошком онлајн окружењу представља кључну карактеристику концепта Веб 2.0, а одређене интернет странице, апликације и технологије постале су његови симболи и/или синоними: YouTube, Instagram, Facebook, Twitter, Википедија, форуми, блогови, инстант поруке, подкаст, аудио и видео стриминг, таговање, итд. Карактеристике Веб 2.0 технологија и повезивање са корисницима интернета на један радикално другачији начин омогућиле су да изузетно велики број корисника интернета једноставно и брзо, уз поседовање елементарних ИТ вештина, приступи мрежи и поставља свој садржај, коментарише и износи своје мишљење и ставове и дели их, без временских и просторних ограничења, са потенцијално изузетно великим бројем других корисника. Веб 2.0 технологије су донеле могућност великом броју људи, не само појединцима који поседују напредније компјутерске вештине, да учествују и да креирају садржаје, да тако генерисан садржај буде виђен или да га чују. Односно, како тврди Манес, у центру ове специфичне „матрице дијалога”, не колекције монолога, налази се корисник на начин на који то до сада никада није био. ${ }^{6}$

Пол Милер (Paul Miller) тврди да је Веб 2.0 партиципативан концепт, да су Веб 2.0 апликације „паметне” апликације које „раде”

5 Chris Anderson, „The Long Tail, in a nutshell”, http://www.longtail.com/about.html (posećeno 02. 02. 2012).

6 Jack M. Mannes, „Library 2.o Theory: Web 2.0 and Its implications for Libraries”, Webology, Volume 3 (2006), http://www.webology.org/2006/v3n2/a25.html (preuzeto 04. 05. 2011). 
за корисника, модуларне и засноване на поверењу, усмерене на дељење, ремиксовање и комуникацију. ${ }^{7}$ Милерово виђење принципа партиципативности је значајно за појам партиципативног веба који се користи и као синоним за Веб 2.0. Овај истраживач наводи податке из 2004. године из којих се види да је 44\% интернет корисника у САД активно учествовало на блоговима путем постављања и дељења садржаја, те предвиђа да ће управо партиципативност постати свепрожимајући аспект наших онлајн живота, будући да делимо наше рецензије књига, коментаришемо локалне ресторане, узимамо учешћа у политичким дебатама итд. Могућност да наше учествовање постане доступно и другим корисницима, аутор види као посебно драгоцен допринос који нам омогућавају Веб 2.0 сервиси. Веб 2.0 се још назива и двосмерни веб, читај/пиши веб, партиципативни веб $^{8}$ и сл. и ове одреднице управо указују на чињеницу да веб није сачињен од статичних страница и једносмерне комуникације. Кејси и Севастинук (Casey, Savastinuk) тврде да партиципативни веб има корене у једноставним технологијама, које омогућавају да колаборативне апликације, попут блога или вики, постану канали корисничког учествовања. „Ове једноставне алатке отварају простор у коме сваки корисник може да сарађује са другим корисницима и да ствара садржај за друге веб сајтове."9

Ипак, наведене технолошке могућности представљају тек почетак процеса у коме треба да подстакнемо и позовемо публику да учествује у креирању и постављању садржаја, уз имплементацију Веб 2.0 технологија. Према налазима истраживања спроведеног 2014. године $^{10}$ поједини библиотекари тврде да још увек не можемо да сма-

$7 \quad$ Paul Miller, "Web 2.0: Building the New Library”, Web Magazine for information professionals, (2005), http://www.ariadne.ac.uk/issue45/miller (preuzeto 08. 01. 2013).

8 Michael Stephens, „Exploring Web 2.0 and Libraries”, Library Technology Reports, 07/08 (2006):10.

9 Michael E. Casey I Laura C. Savastinuk, Library 2.0, A guide to Participatory Library Service, (Medford, New jersey: Information Today, Inc, 2007), 3.

10 Емпиријским истраживањем рађеним у оквиру истраживачке фазе израде докторске дисертације „Библиотека као носилац партиципативних пракси у култури у оквиру информационог друштва“ (Вученовић, Т., Филолошки факултет, Универзитет у Београду, септембар 2016.) је обухваћено 15 библиотекара из Србије. Са одабраним библиотекарима (на основу прелиминарних истраживања) обављени су наменски, 
трамо да је концепт Веб 2.0 имплементиран у већини библиотека, већ да је реч о процесу који са различитом динамиком и успешношћу напредује у овим институцијама културе. Један од разлога би могао бити онај који веома детаљно разматра Дејвид Ли Кинг (David Lee King) у серији чланака ${ }^{11}$ на свом блогу и закључује да нико заправо није објаснио како треба да се започне разговор, како се гради дигитална заједница и како да испричамо оно што желимо у дигиталном простору. Овај аутор позиве на партиципацију дели на пасивне, у којима то чинимо индиректно, и активне, у којима то радимо директно. Пасивни позиви могу бити у различитим облицима и заснивају се на садржају и на коришћењу Веб 2.0 алатки, док активно позивање има једну основну форму - форму питања. Постоје бројни начини на које можемо да питамо наше кориснике да ураде нешто конкретно за институцију и ови позиви представљају веома значајну активност или фазу у оквиру партиципативних пројеката.

Партиципативност у области културе у дигиталном добу значи много више од могућности да онлајн приступимо информацијама и културној баштини, садржају и програмима. Партиципативне праксе данас подразумевају могућност да учествујемо у различитим креативним активностима (читамо, пишемо, постављамо видео и аудио записе о представи коју смо гледали, да учествујемо у дебатама о културним садржајима или културној политици са потенцијално ве-

дубински интервјуи са јасно дефинисаним питањима С обзиром да су се кључна питања на која је тражен одговор односила на креативан ангажман корисника библиотека, за интервјуе су одабрани библиотекари у Србији за које се претходним истраживањем доступних материјала и података утврдило да имају целовиту и јасну слику о овој теми, као и довољно знања и искуства да укажу на проблеме и изазове у овој области. Овим квалитативним истраживањем настојало се да се обухвате библиотеке у нашој земљи које се разликују према средини у којој се налазе, технолошкој опремљености, броју чланова итд, а чији библиотекари експертизом, практичним искуством и активностима могу значајно да допринесу разумевању тема које су у фокусу дисертације. Дакле, ради потпуније слике водило се рачуна - у мери у којој је било могуће, да буду заступљене различите врсте библиотека из градова и варошица, са различитим бројем чланова и веома различитом технолошком инфраструктуром - од библиотеке која нема ни телефон ни интернет до велике библиотеке, која је један од лидера у области примене информационокомуникационих технологија у нашој земљи.

11 David L. King, „Inviting participation”, http://www.davidleeking.com/page/2/?s=Inviting+p articipation (pristupljeno 06. 11. 2014). 
ома великим бројем корисника, итд.) на глобалној рачунарској мрежи, и да на лакши, јефтинији и доступнији начин него што је то био у случај у добу пре интернета, партиципирамо у културном животу, како локалне, тако и глобалне заједнице. Наравно, иако данашњу технологију видимо као темељ партиципативности, не сматрамо да се креативни доприноси публике савремених институција културе заснивају искључиво на технолошкој парадигми, већ настојимо, пре свега, да разумемо шта је потребно да би се партиципитавне праксе реализовале у савременим институцијама културе?

„Интернет је многима омогућио несвакидашњу могућност учешћа у процесу производње и обогаћивања културе која сеже далеко изван локалних граница. Генерално гледано та моћ изменила је тржиште производње и неговања културе... Дигиталне технологије, везане за интернет, могле би произвести конкурентније и живље тржиште за производњу и дистрибуцију културе." 12

Партиципативне праксе у култури користимо у значењу које се односи на партиципацију у области културе у ширем значењу: на партиципацију у продукцији културних артефаката, у прикупљању података и садржаја из области културе, на партиципирање у промоцији и презентацији културне баштине, као и у креирању и реализацији програма културе, на партиципацију у процесима чувања и заштите културних ресурса итд. Концепт партиципативне институције заснивамо пре свега на дубоком уверењу да публика има значајан креативни потенцијал за стварање и дистрибуцију културног садржаја. Појам партиципативности не везујемо само за дигитални свет, нити технолошки аспект партиципативних пракси видимо као најважнији, већ сарадњу са публиком уз примену информационо-комуникационих технологија видимо као релативно нове (и још увек недовољно искоришћене) могућности са великим потенцијалом за учествовање корисника у раду институција и у виртуелном, и у физичком простору установе. Такође, сматрамо да партиципативне праксе у култури нарочито добијају на значају ако имамо у виду наш национални друштвено-политички контекст и чињеницу да је култура у Србији на зачељу лествице када је реч о финансијској и институционалној подршци, те стога публику и кориснике видимо као посебно значајне сараднике и партнере у овој области.

12 Lorens Lesig, Slobodna kultura (Beograd: Službeni glasnik, 2006), 20 - 21. 
Учествовање публике у раду институција културе се као концепт не везује за праксу савремених институција културе и доба интернета већ се, у различитим историјским периодима и у различитим видовима, практикује и у традиционалнијим институционалним оквирима: посетиоци галерија учествују у уметничким перформансима од 60-их година 20. века, чланови библиотека мање или више активно партиципирају у књижевним вечерима које се у простору библиотека организују од давнина и сл. Публика учествује у раду различитих институционалних одбора, али овај вид партиципације, иако потенцијално значајан, резервисан је за ограничен број учесника ${ }^{13}$. Оно што уочавамо као значајну карактеристику комуникационих процеса традиционалних установа је да оне углавном предвиђају релативно пасивно учествовање корисника и једносмеран пренос информација, те своју пажњу пре свега усмеравају на садржај, начин и квалитет његове презентације. Као пример који је илустративан за овакав приступ можемо да наведемо постављање видео опреме у институцији културе која омогућава свим посетиоцима да сниме нешто што је у вези са садржајем који је представљен у тој установи (изложбом, на пример) и, без јасних упутстава резултат ће бити генерисање велике количине незанимљивог и неквалитетног садржаја, који је готово бескористан уколико смо желели да на основу њега сазнамо нешто више о нашој публици или да прикупимо креативан и квалитетан материјал који бисмо потом могли да употребимо за различите институционалне сврхе и програме. За разлику од овако конципиране сарадње, у партиципативним институцијама комуникација би требало да буде вишесмерна, а публика конзумент, стваралац, дистрибутер и критичар културног садржаја.

Том Флеминг сматра да је неопходно да институције културе, да би остале релевантне за јавност, нађу нове начине укључивања јавности као сарадника и учесника ${ }^{14}$. У разматрању особености култу-

13 Појмови: публика, корисник, посетилац, учесник, партиципант- у контексту партиципативних пракси у савременим институцијама културе. Иако имају своја специфична значења ови појмови се у раду користе као синоними, будући да се сви односе на особе које конзумирају различите институционалне садржаје, учитавају своја значења, могу да учествују и да дају одређени допринос културолошким садржајима. Tom Fleming, „Embracing the desire lines - opening up cultural infrastructure”, (2009), 5. https://www.watershed.co.uk/sites/default/files/publications/2011-08-23/Embracing_ the_Desire_Lines.pdf, (pristupljeno 27. 02. 2015). 
ре у дигиталној ери, овај аутор наводи да институције културе данас немају више публику већ партиципанте, кориснике и учеснике на известан начин равне њима, те да је јавност данас много критичнија, слободнија и субверзивнија него икад, али је и отворенија, односно вољнија да учествује и сарађује. Флеминг закључује да је данас много теже институцијама културе, односно данас су - „захтеви захтевнији”. Овај аутор је мишљења да су институције прилично инертне и да се тешко довијају конципирању програма који ће задовољити веома разноврсне потребе данашње јавности.

Истраживање којим је обухваћено 12 институција културе (музеја и галерија) у Великој Британији, показало је да је публика и даље пасивна, да заједница переципира саму себе као потпуно одвојену од процеса унутар поменутих институција ${ }^{15}$, да је за већину институција ангажман публике сведен на консултације а не на сарадњу, те је један од закључака ове студије да је, упркос плановима и улагањима, учествовање и ангажман јавности у раду ових институција, остао на маргинама. Као узроци су, између осталог, наведени: одсуство снажног и посвећеног вођства и стратешког плана, праксе које су засноване на концептима који не подстичу укључивање публике и који је не виде као активног учесника, финансирање пројеката који воде ка партиципацији која није мејнстрим итд. Аутори сугеришу низ веома добрих решења, попут хитног решавања недостатака у сектору, кластере као корак ка оснаживању институција, трансформисање институционалне улоге и усмеравање њеног тежишта ка подршци публици и развоју њених могућности, оснаживању њеног активног односа и учествовања у раду организације, инвестирање у организационе промене итд.

Дакле, како сасвим исправно тврди Мајкл Стивенс: „Технологија може да продужи људске домете али партиципативност захтева ангажованог учесника који се осећа добродошло, удобно и вредновано... партиципативност се дешава када се неко ко је добродошао као гост осећа као да је постао домаћин", и имајући у виду управо

15 „Whoose cake is it anyway, A collaborative investigation into engagement and participation in 12 museums and galleries in the UK", Summary Report by Dr. Bernadette Lynch, Paul Hamlyn Foundation, http://ourmuseum.org.uk/wp-content/uploads/Whose-cake-is-itanyway-report.pdf (pristupljeno 13. 5. 2014). 
чињеницу да технологија представља моћну алатку али да није, сама по себи, покретач партиципативних пракси у култури, поставља једно од кључних питања на које би требало да одговоре савремене институције културе: „Како ћемо отворити врата и позвати све да уђу и партиципирају?" 16 Однос институције културе према новом ангажману корисника и чињеници да публика и установа данас деле и заједнички, информациони простор, преиспитује и група аутора која истражује иновативне сервисе, попут означавања садржаја на глобалној мрежи ${ }^{17}$. Указујући на неопходност темељних промена институционалних пракси које би требало да се ускладе са новом парадигмом учествовања корисника у раду институције, ови аутори износе и тврдњу идеју да применом ових и сличних пракси у домену друштвеног наслеђа много могу да добију и јавност и установа културе, јер корисници осећају велико задовољство када доприносе значајној ствари, а институција постаје богатија бројним подацима, што повећава њену видљивост на вебу, па самим тим, и у реалном свету.

Данас можемо да видимо велики број примера у којима су обични грађани укључени у културолошке процесе који су некада били готово у потпуности у домену кустоса и других експерата. Ови процеси нису настали у доба масовније примене интернета, већ датирају много раније, али су на глобалној рачунарској мрежи добили нове карактеристике, обим и потенцијале. Када разматрамо тему партиципативности у институцијама културе у информационом друштву, важно је да имамо у виду и поменуте резултате истраживања Јакоба Нилсена и његов принцип 90 - 9 - 1, у коме се каже да 90 процената корисника у онлајн заједницама не дају никад никакав допринос садржају на вебу већ само посматрају, 9 процената даје скроман допринос и само 1 проценат заправо генерише садржај на глобалној рачунарској мрежи. Овај принцип партиципативне неједнакости нам је заправо познат и изван веба - веома атрактивни садржаји у музејима нпр. привуку релативно мали број оних који за-

16 Michael Stephens, „The Age of participation”, Library journal, (15. 02. 2012): 40.

17 Johan Oomen i dr., „Emerging Practices in the Cultural Heritage Domain - Social Tagging of Audiovisual Heritage",01.2010, 7.,https://www.researchgate.net/publication/228585569_ Emerging_Practices_in_the_Cultural_Heritage_Domain-Social_Tagging_of_Audiovisual_ Heritage (pristupljeno 20.09. 2014). 
иста оставе коментар, нацртају или напишу нешто и тако допринесу изложби. Ови подаци су важни, јер из њих видимо да нису оправдана веровања у свемоћ веб технологија, упркос бројним предностима које нам доносе - оне очигледно неће од сваког корисника „направити" новинара или писца. Оно што технологије јесу омогућиле и што је новина у односу на учествовање у креирању садржаја у претходним периодима, јесте то да самим посматрањем постајемо важни учесници. YouTube, на пример, показује број прегледа сваког видео клипа на овом популарном друштвеном медију и тако, као посматрачи, утичемо на статус посматраног садржаја. Са друге стране, ако посматрамо тему друштвених медија из институционалног угла и погледамо које могућности постоје да би установе културе постале лидери у управљању онлајн платформама за друштвено умрежавање, увиђамо да је посебно важно да постављају питања и континуирано позивају кориснике да партиципирају на различите начине, да указују на могућности које постоје за корисничку интеракцију и партиципацију, да постављају правила понашања, чувају и користе садржај креиран од стране корисника, промовишу садржај за који сматрају да је добар и сл. Институције културе свакако могу и у партиципативном свету да задрже ауторитет у односу на вредности посетилаца, искуства и понашање заједнице, могу да имплементацијом различитих модела деле и користе садржај створен од стране корисника који истовремено уважава и интересе институције и интересе посетилаца.

Резултати студије у којој је 2014. године анализирано како институције које се баве чувањем културног наслеђа на Новом Зеланду користе онлајн платформе за друштвено умрежавање за развој културе партиципације у оквиру својих дигиталних колекција и сервиса $^{18}$ су показали да су ове установе још увек далеко од поновног осмишљавања сопствене улоге и мисије, од отварања својих колекција за коришћење од стране јавности, за реконтекстуализацију која промовише интерактивност, ангажман, заједничко стварање и размену знања, те да се онлајн платформе за друштвено умрежавање кори-

18 Chern Li Liew, „Participatory Cultural Heritage: A Tale of Two Institutions' Use of Social Media, D-Lib Magazine, Volume 20, 3/4 (2014), http://www.dlib.org/dlib/march14/ liew/03liew.html (pristupljeno 13. 10. 2013). 
сте највише у промотивне сврхе, а не ради подстицања и неговања корисничког ангажмана. Примена Веб 2.0 апликација са циљем неговања партиципативне културе је још увек у експерименталној фази, како су показали и налази поменутог истраживања и очигледно је потребно додатно време и ресурси да би се институције културе адекватно адаптирале и прилагодиле новим начинама продукције и пословања. На пример, чланови јавне библиотеке у мањем граду, како наводи библиотекарка која је учествовала у овом истраживању, учествују у свим активностима библиотеке: у позајмним одељењима, у одељењу за рад са корисницима, у набавној политици библиотеке. Запослени у овој библиотеци углавном кроз разговоре сазнају шта публика жели, како размишља, посматрају шта корисници раде, шта слушају, које књиге бирају итд. и тако се информишу о корисничким потребама. Посебну пажњу посвећују младима, јер сматрају да је важно да се библиотека отвори према њима, да је неопходна примена нових технологија у програмима намењеним овој генерацији, јер је то најбољи, а можда и једини начин да се привуче њихова пажња. Ова библиотекарка наводи да често покрећу различите инцијативе да би укључили публику и мишљења је да велики број корисника много пише, па стога организују често радионице за креативно писање у библиотеци. Корисницичесто пошаљутекст на сајт или на Facebook страну библиотеке под псеудонимом, са молбом да неко прочита и да коментар, и ова комуникација се развија често у веома добру дискусију. То су драгоцени доприноси, сматра ова библиотекарка, која креативан рад корисника види као изузетно значајан за будућност библиотеке. Ипак, наглашава да је борба за читаоце стално присутна и да они још увек више од писања онлајн воле да поразговарају са библиотекаром лице у лице, па онда тај разговор још неко чује, па се поведе прича која може и сатима да траје... Комуникација коју успевају да покрену и испровоцирају им много значи, и онлајн и офлајн. На крају, као добар пример, ова библиотекарка је навела сајт за младе који су направили и који је одлично посећен, корисници су веома активни, шаљу своје песме и приче, коментаришу и укључују се у дискусију о прочитаним књигама или другим темама. Сајт је конципиран тако да једном месечно мењају текстове и сви се завршавају тамо где је 
најинтересантније, јер им је циљ да провоцирају кориснике да изађу из куће, да оду до библиотеке и позајме књигу.

Дакле, у току је процес у коме се, посебно захваљујући све масовнијој употреби информационо-комуникационих технологија збива важна промена у културној и друштвеној сфери - корисници као партиципанти у овим сферама постају све бројнији, прикључују се различитим активностима, без временских и географских ограничења, имају могућности да буду активнији и интерактивнији, вештији и самосталнији, а самим тим и - утицајнији. Наравно - није све идилично у социјалном вебу, како се наводи и у студији у којој се, између осталог, разматрају партиципативне праксе у домену културног наслеђа, и износи тврдња да предности партиципације подривају један изузетно важан процес - процес филтрирања информација од стране експерата који доприноси њиховом квалитету. Аутори ове студије предвиђају и да ће институција које се баве културним наслеђем у будућности „... бити отворене, изграђене на интилигентној инфраструктури и на концепту партиципативности имеђу различитих циљних јавности." ${ }^{19}$ Још једна од потешкоћа представља, на пример, чињеница да многе веб апликације које су бесплатне а веома корисне за комуникацију са корисницима - не обезбеђују директну технолошку подршку за кориснике и треба бити припремљен на овакве околности и покушати да, на пример, кроз адекватну обуку особља у институцији културе - ови изазови буду превазиђени. Са друге стране, иако не постоје географска и временска ограничења када је реч о глобалној рачунарској мрежи, постоје бројна друга: недостатак адекватног образовања и познавања различитих вештина, велике разлике у економском и социјалном статусу које доводе и до разлика у степену дигитализације и информатизације појединих земаља, надзор и контрола садржаја на интернету и сл.

Нина Симон дели партиципативне пројекте на следећи начин: у категорију контрибутивних пројеката сврстава пројекте у којима се од посетилаца (публике) захтева да допринесу процесу који је

19 Johan Oomen i Lora Aroyo, „Crowsourcing in the Cultural Heritage Domain: Opportunities and Challenges", C\&T'11,QUT, (2011), 147, http://www.iisi.de/fileadmin/IISI/upload/2011/ p138_oomen.pdf (pristupljeno 11. 01. 2014). 
контролисан од стране институције - специфичним и ограниченим објектима, идејама или акцијама (табла за коментаре); у сарадничким (колаборативним) пројектима публика је позвана да буде активан партнер у стварању институционалних пројеката - који су настали и до краја су контролисани од стране институције; у трећој категорији, у пројектима заједничког стварања, чланови заједнице од почетка раде са особљем институције на дефинисању циљева пројекта и генерисању програма који су засновани на интересима заједнице. Ауторка предлаже укључивање четвртог модела овој типологији - „хостованог модела”, и наводи да у ову групу спадају пројекти у којима институција део својих ресурса даје/уступа за представљање програма које предлажу екстерне циљне јавности, те је у овим случајевима институција минимално укључена у пројекат. На суштинско питање: „Како институције културе могу да се поново повежу са јавношћу и покажу своју релевантност у савременом животу”?, Симон даје кратак одговор: „Верујем да то могу да учине тако што ће позвати људе да се активно укључе као културни учесници а не као пасивни конзументи". ${ }^{20}$ Јер, посетиоци очекују, сматра ауторка, могућност да дискутују, деле и ремиксују оно што конзумирају, те ако могу активно да учествују - сарађују са институцијама културе, онда ова места постају централна у културном животу заједнице. Ауторка дефинише партиципативну институцију културе (и у овом значењу се овај појам користи у овом раду), као место где посетиоци могу да стварају, деле и повезују се једни са другима око садржаја, као институцију која се ствара и њом се управља заједно са корисницима. Уважавајући ангажман корисника и сматрајући га драгоценим за савремене институције културе, важно је да на овом месту нагласимо да планирање и реализација ових пројеката треба пре свега да буду усклађени са мисијом институције и њеним кључним вредностима, те да се постарамо да се партиципативним техникама уједно развија и унапређује визија и позиција саме институције.

Дакле, да би партиципативни пројекти били успешни значајне компоненте су: добро познавање институционалних и корисничких потреба и њихово континуирано балансирање, јасна идеја 
шта пројектом желимо да постигнемо и добар план, веродостојно обећање које ће нашим посетиоцима дати лични разлог да се врате, ефикасне алатке, солидан буџет, адекватан договор са учесницима. Потребно је стога да обезбедимо и континуиране могућности за боље упознавање особља и публике, и као добро место за почетак, многи истраживачи предлажу информативни деск, који има већина институција културе. Сваки члан особља неколико сати месечно може да ради на овом месту и одговара на питања посетилаца, разговара са њима и на тај начин их боље упознаје. Свакако, за партиципативне пројекте у институцијама културе важан је и баланс различитих искустава: културолошког, социјалног, едукативног и комуникацијског. Мисија институција културе (подизање свести о значају културне баштине, прикупљање садржаја и различитих ресурса, подстицање и неговање креативности и критичког мишљења итд.) може да се оствари управо кроз реализацију партиципативних пројеката, како је и указано.

Такође, сматрамо да треба посебно истаћи значај едукације и неопходност укључивања образовних програма у припреме за партиципативне пројекте, јер су за спровођење ових пројеката, како је наведено, и особљу и публици потребне нове вештине и знања, будући да се разликују од традиционалних институционалних пројеката. Значајно је да се напомене да планирање партиципативних пројеката треба да буде усклађено са већ постојећим моделима и начинима рада у институцији и да треба да почне са особљем јер, као и публици, и особљу и волонтерима у институцијама културе је потребан подстицај и охрабрење да се окушају у нечему што је за њихову праксу сасвим ново. Први корак на том путу је едукација и њихово активно укључивање у планирање и развој партиципативних пракси. Реализација партиципативних пројеката је праћена и бројним изазовима међу којима се као највећи издвајају: финансирање, управљање, недостатак квалитетне евалуације и иницијативе за стратешку промену правца којим ће се институција усмерити ка ангажовању и укључивању заједнице, ка томе да постане њен друштвени центар. Приликом планирања партиципативних пројеката потребно је да се води рачуна о томе да ли корисници желе и на који начин да партиципирају и да се, имајући у виду индивидуалне по- 
требе, осмисли идеја која ће моћи да се примени на већу или мању групу људи, те да се јасно каже шта очекујемо и шта нудимо публици.

На крају је свакако важно да се укаже и на вештине које су потребне данашњем кориснику да би остварио стваралачки потенцијал у култури и друштву, стога указујемо на образовни потенцијал партиципативних пракси и техника у култури. Наиме, ове технике помажу посетиоцима да развију специфичне вештине на које се често реферише као на вештине 21. века или новомедијску писменост: сарадња и интеракција са људима различитог порекла, генерисање креативних идеја (самостално или у групи); приступ, евалуација и тумачење различитих информационих извора; анализа, адаптација и стварање медијских производа, вештина самосталног усмеравања учења; адаптација на различите радне улоге, ситуације и просторе, одговорно понашање у коме имамо на уму интересе шире заједнице. Постоје образовни сараднички пројекти које иницирају институције које превасходно перципирају чин партиципације као драгоцено искуство сазнања и учења, а сва је прилика да ће број оваквих пројеката расти што више институција буде стављало акценат на партиципативне вештине учења и дигиталну писменост.

\section{Списак литературе}

Anderson, C., „The Long Tail, in a nutshell”, http://www.longtail.com/about.html.

Casey, E. M. i Savastinuk, C. L., Library 2.0, A guide to Participatory Library Service, (Medford, New jersey: Information Today, Inc (2007).

Fleming, T., „Embracing the desire lines - opening up cultural infrastructure”, (2009). https://www.watershed.co.uk/sites/default/files/publications/2011-08-23/Embracing the Desire Lines.pdf.

Joubert M. i Wishart J., „Participatory practices: Lessons learnt from two initiatives using online digital technologies to build knowledge", Computers and education 59 (2012), 111., prema: Adamic, L. A., Wei, X., Yang, J., Gerrish, S., Nam, K. K., \& Clarkson, G. S. (2010).

King, D. L., „Inviting participation”, http://www.davidleeking.com/page/2/?s=Inviting+p articipation

Lesig, L., Slobodna kultura (Beograd: Službeni glasnik (2006).

Mannes, M. J., "Library 2.o Theory: Web 2.0 and Its implications for Libraries”, Webology, Volume 3 (2006), http://www.webologv.org/2006/v3n2/a25.html. 
Miller, P., "Web 2.0: Building the New Library”, Web Magazine for information professionals, (2005), http://www.ariadne.ac.uk/issue45/miller .

Oomen J. i dr., „Emerging Practices in the Cultural Heritage Domain - Social Tagging of Audio visualHeritage",01.2010,https://www.researchgate.net/publication/228585569_ Emerging_Practices_in_the_Cultural_Heritage_Domain-Social_Tagging_of_ Audiovisual_Heritage.

O'Reilly, T., „Web 2.0: Compact Definition?”, http://radar.oreilly.com/2005/10/web-20compact-definition.html .

Stephens, M., „Exploring Web 2.0 and Libraries”, Library Technology Reports, 07/08 (2006). Stephens, M., „The Age of participation”, Library journal, 2012.

"Whoose cake is it anyway, A collaborative investigation into engagement and participation in 12 museums and galleries in the UK", Summary Report by Dr. Bernadette Lynch, Paul Hamlyn Foundation, http://ourmuseum.org.uk/wpcontent/uploads/Whose-cake-is-it-anyway-report.pdf.

\section{Tamara Vucenovic}

Radio Belgrade

\section{NEW PARADIGM OF CULTURE: PARTICIPATORY PRACTICES IN CONTEMPORARY CULTURAL INSTITUTIONS}

\section{Summary}

The paper "New Paradigm of Culture: Participatory Practices in Contemporary Cultural Institutions" points to the Web and Internet technologies as the basis of participativity, to the notion of participatory practices in culture, as well as to the claims of Nina Simon that cultural institutions can re-connect with the public and show relevance in modern life by inviting people to actively engage as cultural participants instead of being only passive consumers. The paper also points to research that shows how collaboration with the public through the use of ICTs is still viewed as a relatively new and underused opportunity. The fact is that it is necessary to balance between the needs of institutions and the needs of individuals, and to respect copyrights and other challenges that accompany the realization of participatory projects in contemporary cultural institutions.

Key words: culture, ICT, Web, participatory practices, cultural institutions, new paradigm. 